\title{
The Adaptation of Turkish Health Literacy Scale for Literate Syrian Adult Refugees Living in Turkey: A Reliability-Validity Study
}

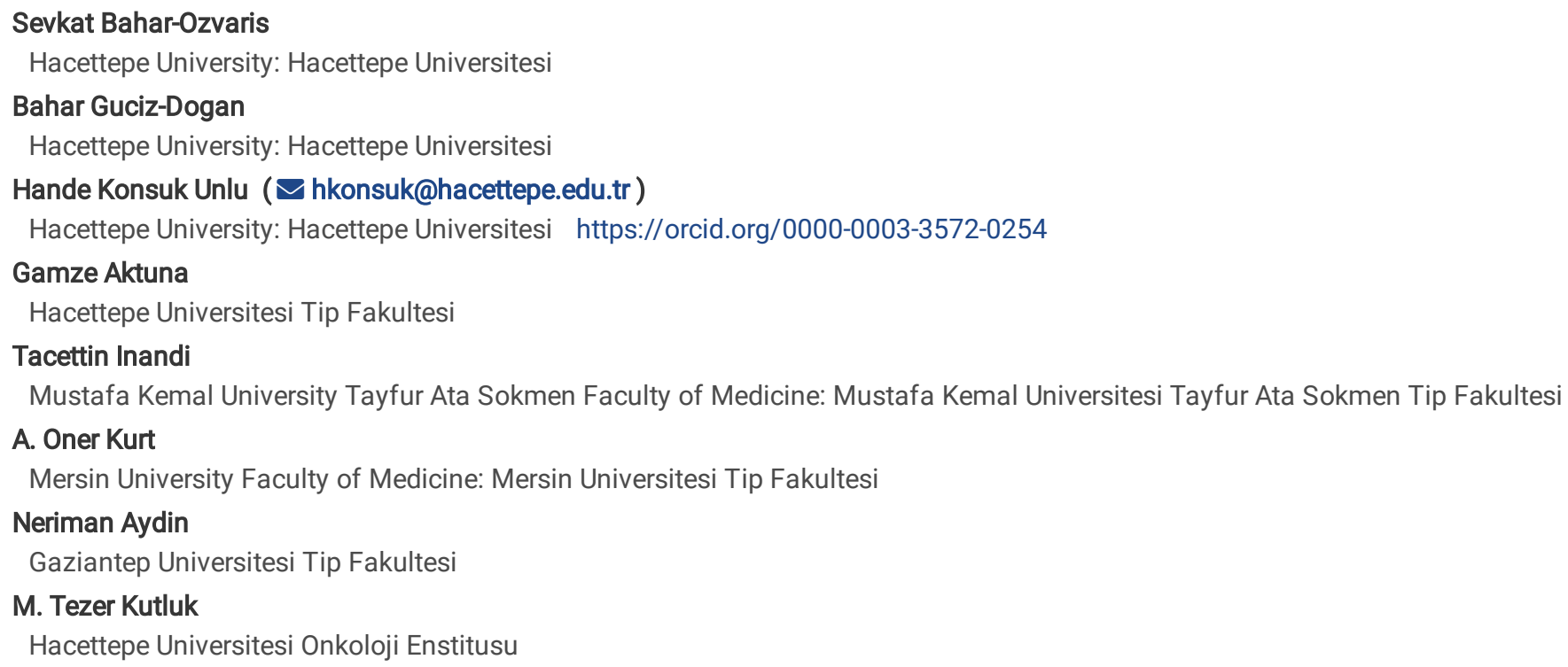

\section{Research Article}

Keywords: Health Literacy Scale (HU-HLS), Scale Adaptation, Reliability-Validity, Syrian Refugees, Confirmatory Factor Analysis

Posted Date: May 7th, 2021

DOI: https://doi.org/10.21203/rs.3.rs-487416/v1

License: (c) (i) This work is licensed under a Creative Commons Attribution 4.0 International License. Read Full License

Version of Record: A version of this preprint was published at Conflict and Health on August 28th, 2021. See the published version at https://doi.org/10.1186/s13031-021-00401-5. 


\section{Abstract}

\section{Background}

There is a big Syrian refugee population which counts more than 3.5 million since the year 2011, and continuously growing. This situation causes various problems, mainly while obtaining health services. In planning the migrant health services, for the policy makers of host countries, health literacy level of migrants is an important measure. Determination of health literacy level of Syrian refugees in Turkey would be supportive for planning some interventions to increase health services utilization, and health education and health communication programs. An "original health literacy scale" for 18-60 years of age Turkish literate adults (Hacettepe University Health literacy Scale-HLS) was developed to be used as a reference scale in 2018. It would be useful to compare the health literacy level of Turkish adults and Syrian adult refugees resided in Turkey with an originally developed scale. For this reason, it was aimed to adapt the HLS-Short Form in Syrian refugees.

\section{Methods}

This methodological study was carried out between 2019-2020 in three provinces of Turkey where the Syrians live intensively. The data was collected by pre-trained, Arabic speaking 12 interviewers and three supervisors via a questionnaire on household basis. At first, the original Scale and questionnaire were translated into Arabic and backtranslated. The questionnaire and the Scale was pre-tested on 30 Syrian refugees in Ankara Province. A total of 1254 refugees were participated to the main part of study; 47 health-worker participants were excluded from the validity-reliability analysis. Confirmatory factor analysis (CFA) was performed. Cronbach's alpha and Spearman-Brown coefficients were calculated.

\section{Results}

Of the participants, $52.9 \%$ was male; $26.1 \%$ had secondary level or less; almost half of them had moderate economic level; $27.5 \%$ could not speak Turkish. The Cronbach's Alpha was 0.75, Spearman-Brown Coefficient was 0.76; RMSEA =0.073, CFI = 0.93, TLI = 0.92 and GFI = 0.95 for the Scale. The Cronbach's Alpha was 0.76, Spearman-Brown Coefficient was 0.77; RMSEA $=0.085, \mathrm{CFI}=0.93, \mathrm{TLI}=0.91$ and GFI $=0.95 \mathrm{for}$ selfefficacy part.

\section{Conclusion}

In conclusion, the adapted HLS would be a reliable instrument to evaluate the health-literacy level of Syrians living in Turkey and could give an opportunity to compare the host country's $\mathrm{HL}$ with the refugees by using the same scale.

\section{Background}

After opening the borders of Turkey to Syrians, since 2011, the number have increased 3.6 million registered refugees. Great amount of refugees are living mostly in province centers, with the highest numbers in Istanbul, Gaziantep, Şanlıurfa and Hatay provinces (Mol, 2021). Migrants with legal status could utilize Migrant Health Centers (MHC) and Migrant Health Units (MHU) in order to obtain primary health care services (PHC) free of charge provided by the Government. $175 \mathrm{MHC}$ and $785 \mathrm{MHUs}$ were established in 29 cities in Turkey. As of August 2020, 2520, Syrian health personnel and 966 patient referral guides (translators) had been trained and are providing services in MHCs/MHUs across the country $(\mathrm{MoH}, 2020)$.

Migration involves a much deeper adaptation mechanism than individual adjustments to new environments and is in a negotiation process with social, political and economic forces. In this context, immigration should be considered as a fundamental social determinant of health, since it is a lived experience that directly affects health and well-being (Castañeda et al, 2015).

The continuing growth of refugees in Turkey sources some adaptation problems. According to some studies, problems stated by the migrants while obtaining health services were lack of trust, fear of healthcare personnel, lack of health insurance, lack of communication and consequently not being able to give informed consent, and inability to control privacy (Koçan et al., 2016; Alkan et al., 2016; Demir et al., 2016). Language barrier might lower benefiting refugees from health services which might affect the adherence to the treatment (Meydanlioglu et al., 2015). In some recent studies, it was suggested that migrants utilize less compared with the host comminity (UN, 2017). Migrants have poorer access to health care services, and use less information, health promotion, disease prevention (WHO, 2013).

As it is stated in the WHO document related to health promotion, "health literacy promotes empowerment, which in turn is vital for achieving the internationally agreed health and development goals as well as the emerging threats such as from the pandemic influenza, climate change and non-communicable diseases" (WHO 2020 Track 2). Unsufficient health literacy is highly related to reduced access to health services, trouble in managing health problems, limited understanding health-related information and ability in making logical decisions interrelated health issues (Naus 2018). At the end, limited health literacy provokes ineffectual use of health-care resources, resulting with increased personal and public 
expenditures. Health literacy level of migrants is an important indicator for the policy makers of host countries in planning the migrant health services. Determination of health literacy level of Syrian refugees in Turkey would be supportive for health services utilization as well as health education and health communication programs that will change the health behaviors. Health literacy scales are valuable tools to determine the health literacy level.

An "original health literacy scale" for Turkish literate adults between 18-60 years of age (Hacettepe University Health literacy Scale-HLS) was developed to be used as a reference scale in 2018 (Bahar Özvarış et al, 2018). After developing the 72 items long form, a short form (24 health literacy related items +16 self-efficacy statements) was also validated. The analysis showed that Scale could be used as a reference scale to assess the health literacy level for Turkish literate adults. In order to compare the health literacy level of Turkish adults and Syrian adult refugees resided in Turkey with an originally developed scale, it was aimed to adapt the HLS-Short Form in Syrian refugees.

\section{Methods}

\section{Participants and procedure}

This methodological study was carried out in Hatay, Mersin and Gaziantep provinces where the Syrians live intensively in Turkey between 2019-2020. The data was gathered by pre-trained 12 Arabic speaking interviewers (half female) and three supervisors. The validity-reliability study was carried out on the Syrian refugees in the same age group. The data were collected via a questionnaire (including questions related to some socio-demographical characteristics and HLS) on household basis. Approximately 400 Syrian refugees, equal number from each gender in each age group (18-29, $n=459,38 \% ; 30-44, n=422,35 \% ; 45-60, n=326,27 \%)$ were randomly recruited from each province (Gaziantep $n=$ 382 , Hatay $n=431$, Mersin $n=395$ ). A total of 1,254 refugees were participated to the study. Forty-seven health worker participants were excluded from the validity-reliability analysis in order not to ruin the results as was done in the validity analysis of the original scale. Final analysis was performed with 1207 participants.

\section{Instruments}

The short form of the HLS-Turkish version consisted of two parts: A 24-items knowledge-based health literacy part (one dimension) and a 16statements self-efficacy part. Every item of the health literacy part was scored as "1": true answer, "0": wrong answer. The minimum-maximum scores could be obtained are 0-24. The self-efficacy part of the scale has one-dimension also. The statements were scored as 1 : never, 2 : sometimes, 3: always. The minimum-maximum scores could be obtained are $16-48$. Due to the different scoring system of the parts, a total score could not be calculated.

The reliability-validity results showed that HLS-Short Form is a valid and reliable tool. The reliability results of the Health Literacy Scale are as follows: Cronbach's alpha $=0.84$ for internal consistency and Spearman-Brown $=0.78$ for split-half reliability; Root Mean Square Error of Approximation $(\mathrm{RMSEA})=0.049$, Goodness of fit $(\mathrm{GFI})=0.94$, Adjusted Goodness of Fit $(\mathrm{AGFI})=0.93$ and Normed Fit Index $(\mathrm{NFI})=0.94$. The reliability results of the Self-Efficacy part are Cronbach's alpha $=0.83$ and for internal consistency and Spearman-Brown $=0.73$ for split-half reliability; $\mathrm{RMSEA}=0.068, \mathrm{GFI}=0.94, \mathrm{AGFI}=0.91$ and $\mathrm{NFI}=0.94$ (Bahar Özvarış et al, 2018).

\section{Statistical Analysis}

Data entry and evaluation were conducted through statistical package program IBM SPSS 23.0. The validity and reliability analysis were performed using The R Project for Statistical Computing (ver. 4.0.0) program. Confirmatory factor analysis (CFA) based on polychoric correlations diagonally was applied to confirm the factor structure of the scale. Diagonally weighted least squares (DWLS) method was used to get more accurate parameter estimates. In addition, modification indices were also obtained. If needed, the correlation between error terms was added to the model according to high modification indices. In order to demonstrate the reliability, the Cronbach's alpha reliability coefficient, which shows internal consistency, and Spearman-Brown coefficients, which shows the two-half reliability, were calculated. The difficulty and discrimination coefficients and Cronbach's alpha if item deleted statistics calculated when the item was deleted. To demonstrate criterion validity, the average scores of Health-Literacy part and Self-Efficacy part of the health workers and non-health workers were compared via independent samples t test; $p<0.05$ was accepted as significance level.

\section{Results}

Of the participants, $52.9 \%$ was male; almost half of them was university graduated; $60.7 \%$ was married and living with spouse; $47.6 \%$ currently working; one-fourth stated their economic status as below moderate or poor. Mother tongue was Arabic in $98.4 \%$ of the participants; another $1.5 \%$ stated thir mother tongue as Kurdish or Turkish, and $27.5 \%$ did not speak Turkish. One-fifth of the participants had at least one chronic disease and $48.2 \%$ had health insurance (Table 1). 
Some Characteristics of Participants (Turkey, 2019)

\begin{tabular}{|c|c|c|}
\hline Characteristics & $\mathrm{n}^{*}$ & $\%$ \\
\hline \multicolumn{3}{|l|}{$\operatorname{Sex}(n=1207)$} \\
\hline Male & 639 & 52.9 \\
\hline Female & 569 & 47.1 \\
\hline \multicolumn{3}{|l|}{ Educational Status $(n=1200)$} \\
\hline Primary school & 80 & 6.7 \\
\hline Secondary school & 233 & 19.4 \\
\hline High school & 297 & 24.8 \\
\hline University & 590 & 49.2 \\
\hline \multicolumn{3}{|l|}{ Marital Status $(n=1205)$} \\
\hline Never married & 386 & 32.0 \\
\hline Married and living with spouse & 731 & 60.7 \\
\hline Widowed/Divorced/Separated & 88 & 7.4 \\
\hline \multicolumn{3}{|c|}{ Working status in Turkey $(n=1206)$} \\
\hline No & 628 & 52.4 \\
\hline Yes & 573 & 47.6 \\
\hline \multicolumn{3}{|l|}{ Economic Status $(n=1205)$} \\
\hline Very good & 57 & 4.7 \\
\hline Good & 278 & 23.1 \\
\hline Moderate & 566 & 47.0 \\
\hline Below Moderate & 203 & 16.8 \\
\hline Poor & 101 & 8.4 \\
\hline \multicolumn{3}{|l|}{ Speaking Turkish $(n=1202)$} \\
\hline No & 330 & 27.5 \\
\hline Moderate & 493 & 41.0 \\
\hline Yes & 379 & 31.5 \\
\hline \multicolumn{3}{|l|}{ Health insurance $(n=1186)$} \\
\hline No & 604 & 50.1 \\
\hline Yes & 582 & 48.3 \\
\hline \multicolumn{3}{|c|}{ Having Any Chronic Disease $(n=1203)$} \\
\hline No & 951 & 79.1 \\
\hline Yes & 252 & 20.9 \\
\hline
\end{tabular}

\section{Adaptation Process Of The Scale} Language Validity

As the first stage, the Scale and questionnaire were translated into Arabic by an expert whose native language is Arabic and speaks Turkish at a good level. Another expert whose mother tongue is Arabic and speaks Turkish fluently made the back translation. The back translated Scale 
was compared to the original Scale by the research team and Turkish Language experts, and the process of Arabic translation of the Scale was ended.

The questionnaire and the first draft of the Scale was pre-tested through an Arabic speaking interviewer on 30 Syrian refugees from different age groups (18-29, 30-44, 45-60) in Ankara Province. The results of the pilot study were evaluated by the research team with the help of the Arabic-Turkish translators and the final version of the Scale was obtained.

\section{The Validity-Reliability Results of Health Literacy part of the Scale Item Analysis Results}

Cronbach's alpha statistics when item deleted, difficulty and discrimination values of items were obtained. The difficulty levels of items ranged between 0.29 and 0.93 . All of the items were positively correlated with the total score and ranged between 0.14 and 0.69 . Item 9 and Item 12 were excluded by taking experts' opinions, since item-total correlation were less than 0.20 . After that, reliability analysis was performed again and the item statistics for remaining items were given in Table 2. According to item analysis result, difficulty levels of items varied between 0.29-0.93 and item-total correlation values varied between $0.22-0.72$ for the one-dimension Health Literacy part of the Scale with 22 items.

Table 2

Item Statistics and Reliability Values of Health Literacy part of the Scale

\begin{tabular}{|c|c|c|c|}
\hline & Difficulty & $\begin{array}{l}\text { Discrimination Values } \\
\text { (Point Biserial Correlation) }\end{array}$ & $\begin{array}{l}\text { Cronbach's Alpha } \\
\text { (when item deleted) }\end{array}$ \\
\hline Item1 & 0.93 & 0.37 & 0.75 \\
\hline Item2 & 0.84 & 0.46 & 0.74 \\
\hline Item3 & 0.93 & 0.31 & 0.75 \\
\hline Item4 & 0.76 & 0.45 & 0.74 \\
\hline Item5 & 0.67 & 0.48 & 0.74 \\
\hline Item6 & 0.72 & 0.42 & 0.74 \\
\hline Item7 & 0.87 & 0.56 & 0.74 \\
\hline Item8 & 0.89 & 0.56 & 0.74 \\
\hline Item10 & 0.76 & 0.52 & 0.74 \\
\hline Item11 & 0.55 & 0.36 & 0.75 \\
\hline Item13 & 0.40 & 0.29 & 0.75 \\
\hline Item14 & 0.77 & 0.22 & 0.75 \\
\hline Item15 & 0.93 & 0.72 & 0.74 \\
\hline Item16 & 0.79 & 0.51 & 0.74 \\
\hline Item17 & 0.29 & 0.25 & 0.75 \\
\hline Item18 & 0.85 & 0.60 & 0.74 \\
\hline Item19 & 0.91 & 0.45 & 0.75 \\
\hline Item20 & 0.80 & 0.70 & 0.73 \\
\hline Item21 & 0.78 & 0.68 & 0.73 \\
\hline Item22 & 0.73 & 0.61 & 0.73 \\
\hline Item23 & 0.78 & 0.26 & 0.75 \\
\hline Item24 & 0.74 & 0.22 & 0.76 \\
\hline \multicolumn{2}{|c|}{ Cronbach's Alpha } & \multicolumn{2}{|l|}{0.75} \\
\hline \multicolumn{2}{|c|}{ Spearman-Brown Coefficient } & 0.76 & \\
\hline
\end{tabular}

The internal consistency was 0.75 , which showed a high level of reliability. The Spearman-Brown coefficient result showed that split-half reliability was sufficient. 


\section{Confirmatory Factor Analysis Results}

In order to confirm the construct validity, confirmatory factor analysis (CFA) based on polychoric correlations was applied since there was a theoretical basis for one-dimensionality with 22 items, which was formed by item analysis and experts' opinions. The path diagram was given in Fig. 1.

As seen in Fig. 1, standardized factor loadings ranged between 0.12 and 0.55 . As the fit indices, RMSEA was 0.083 , CFI (Comparative Fit Index) was 0.91 , TLI (Tucker-Lewis Index) was 0.90 and GFI was 0.93 . According to the modification indices, the results suggested to add correlation between the error terms of Item 20 and Item 21. After taking experts' opinions, it was decided that this modification was appropriate. The analysis was repeated again and fit indices were calculated. The RMSEA was found as 0.073 which reflects a good fitness. The other fit indices were $\mathrm{CFI}=0.93, \mathrm{TLI}=0.92$ and $\mathrm{GFI}=0.95$. The results demonstrated that model had a very good fitness and the construct validity was confirmed.

\section{The Validity-Reliability Results of Self-Efficacy Part of the Scale Item Analysis Results}

Cronbach's alpha statistics when item deleted, difficulty and discrimination values of items were obtained. All of the items were positively correlated with the total score and ranged between 0.12 and 0.62 . Item 14 was excluded by taking experts' opinions, since item-total correlation was less than 0.20 . Reliability analysis was performed again and the item statistics for remaining items were given in Table 3 . As seen from the table, item-total correlation values of Item 15 and Item 16 were less than 0.20 . After taking expert's opinions, it was decided to keep these items that they could negatively affect the content validity if excluded. Item-total correlation values varied between $0.12-0.63$ for the one-dimension Self-Efficacy part of the Scale with 15 items.

Table 3

Item Statistics and Reliability Values of Self-Efficacy Part of the Scale

\begin{tabular}{|llll|}
\hline & Difficulty & $\begin{array}{l}\text { Discrimination Values } \\
\text { (Point Biserial Correlation) }\end{array}$ & $\begin{array}{l}\text { Cronbach's Alpha } \\
\text { (when item deleted) }\end{array}$ \\
\hline Item1 & 2.02 & 0.48 & 0.74 \\
\hline Item2 & 2.02 & 0.60 & 0.73 \\
\hline Item3 & 1.75 & 0.54 & 0.74 \\
\hline Item4 & 2.18 & 0.60 & 0.73 \\
\hline Item5 & 1.80 & 0.63 & 0.73 \\
\hline Item6 & 2.30 & 0.31 & 0.76 \\
\hline Item7 & 2.30 & 0.61 & 0.73 \\
\hline Item8 & 2.49 & 0.33 & 0.76 \\
\hline Item9 & 2.04 & 0.53 & 0.74 \\
\hline Item10 & 1.86 & 0.27 & 0.76 \\
\hline Item11 & 1.92 & 0.49 & 0.74 \\
\hline Item12 & 2.33 & 0.21 & 0.76 \\
\hline Item13 & 2.12 & 0.26 & 0.76 \\
\hline Item15 & 2.58 & 0.17 & 0.77 \\
\hline Item16 & 2.53 & 0.12 & 0.77 \\
\hline Cronbach's Alpha & 0.76 & \\
\hline Spearman-Brown Coefficient & 0.77 & \\
\hline If & & 0.73 & \\
\hline
\end{tabular}

The internal consistency was 0.76 , which signed a high level of reliability. The Spearman-Brown coefficient showed that split-half reliability was sufficient.

\section{Confirmatory Factor Analysis Results}


In order to confirm the construct validity, confirmatory factor analysis (CFA) based on polychoric correlations was applied since there was a theoretical basis for one-dimensionality with 15 items, which was formed by item analysis and experts' opinions. The path diagram was given in Fig. 2.

Standardized factor loadings ranged between 0.07 and 0.72 (Fig. 2). The fit indices were as follows: RMSEA = 0.085, CFI = 0.93, TLI = 0.91 and $\mathrm{GFI}=0.95$. The model had a very good fitness and the construct validity was confirmed.

\section{Criterion Validity}

There were 47 health workers among the participants. In order to demonstrate criterion validity, age and gender distributions of 47 health workers in the study group, who were not included in the reliability-validity analysis, were obtained for each province. From the remaining 1207 participants, 47 non-health workers selected randomly with the same gender and age distribution as health workers selected. The summary statistics were given in Table 4.

Table 4

The summary statistics of the scores for health and non-health workers

\begin{tabular}{|c|c|c|c|c|}
\hline & \multicolumn{2}{|c|}{ Health Literacy Part Scores } & \multicolumn{2}{|c|}{ Self-Efficacy Part Scores } \\
\hline & Non-Health Workers & Health Workers & Non-Health Workers & Health Workers \\
\hline Mean \pm SD & $16.36 \pm 3.90$ & $18.72 \pm 2.80$ & $32.66 \pm 5.69$ & $35.2 \pm 5.81$ \\
\hline Median & 18.0 & 20.0 & 33.0 & 37.0 \\
\hline$Q_{1}-Q_{3}$ & $14.0-19.0$ & $17.0-21.0$ & $30.0-37.0$ & $31.0-39.0$ \\
\hline Min-Max & $3-21$ & $13-22$ & $20-42$ & $22-44$ \\
\hline Count & 47 & 47 & 47 & 47 \\
\hline$p$-value & $0.005^{*}$ & & $0.041^{*}$ & \\
\hline \multicolumn{5}{|c|}{ SD: Standard deviation, $\mathrm{Q}_{1}: 1$ st quartile, $\mathrm{Q}_{3}: 3$ rd quartile, Min: Minimum, Max: Maximum } \\
\hline
\end{tabular}

The mean total Health Literacy part scores for non-health workers and health workers were 16.36 \pm 3.90 and $18.72 \pm 2.80$, respectively. The mean total Self-Efficacy part scores for non-health workers and health workers were $32.66 \pm 5.69$ and $35.2 \pm 5.81$, respectively. When the groups were compared in terms of Health Literacy and Self-Efficacy scores, statistically significant difference was found between health and nonhealth workers. Thus, the criterion validity of the scale was confirmed.

\section{Discussion}

Refugees are transported to host countries with a range of different health and cultural beliefs, and previous experiences. These differences affect their health outcomes at every point of interaction with the host country's healthcare system (Kostareva et al, 2020). Cultural beliefs about health and illness are complement to ability of a patient in understanding and behaving on health-related instructions (Shaw et al, 2009).

Health literacy is significantly and consistently associated with the quality of care. Refugees with adequate health literacy in reading hospital documents reported higher level of quality of medical care compared to with poor health literacy (Calvo, 2016). The language barrier for refugees poses a major problem in health care services related situations that could prevent refugees from seeking and receiving appropriate health services (Mantwill \& Schulz, 2017).

It would not be wrong to argue that refugees are affected more by all other social determinants of health than the citizens of the host country. In a study conducted in Canada, education level, employment status and income found to be mediated health literacy and it was stated that efforts to improve health literacy can benefit everyone (Omariba \& $\mathrm{Ng}, 2015)$. This context reveals how important health literacy studies are for immigrants.

Health literacy scales are important tools for assessing the health literacy level. There are significant differences in which dimensions are taken into consideration regarding health literacy (Sørensen et al., 2012; Poureslami et al., 2017). In different papers, health literacy defined as a combination of skills including the 'print literacy', 'numeracy or quantitative literacy' and 'oral literacy' (Berkman et al., 2010; Altin et al., 2014). In other respect, most widely discussed approaches to literacy classification included 'functional, interactive, and critical literacy' levels. This comprehensive approach indicated that the different levels of literacy progressively allowed for greater autonomy and personal empowerment (Nutbeam, 2000, 2008). TOFHLA evaluates the reading comprehension and numeracy (Parker, 1995); REALM identifies the patient's reading 
skills (Davis et al. 1991); REALM-R is only a word recognition test (Bass et al, 2003), Newest Vital Sign (NVS) test, assesses reading and interpretation skills (Weiss et al, 2005). However, the original Turkish HLS which adapted for Arabic language in this study, includes items related to the three levels of cognitive domain of Bloom's Taxonomy ("knowledge", "comprehension" and "application") as well as the selfefficacy statements, based on the affective domain. At the same time, original Turkish HLS assesses "disease prevention and health promotion", and "treatment and access to health services" within the aforementioned context (Bahar Özvarış et al., 2018).

There are some adopted Arabic language health literacy scales existing (Al-Jumaili et al., 2015; Wångdahl et al., 2015; WHO, 2020; Siddiqui, 2017). However, there is no comprehensive HLS developed for healthy adults such as the Turkish HLS which is the first Turkish original scale of its kind as mentioned above. The validity study of the original scale was performed on the data collected at community level with household visits opposite of most of the other HLSs developed by interviewing people recruited to the health institutions. Working with a communitybased sample by visiting households rather than working with specific patient or service user groups in health care settings, and application of the scale to a geographically and culturally diverse population are among the other significant strengths of the original Turkish scale.

It is important to use a standard tool when it is aimed to compare health literacy levels of different groups. The original Turkish HLS was adopted to Arabic in order to compare the health literacy level of Turkish adults and Syrian adult refugees resided in Turkey. It is also important to use this adopted scale related to the cultural similarity of the two communities' which sources from history of both countries. There are various similar Arabic and Turkish words in two languages also.

The Cronbach's alpha value of the health literacy part of the scale was found as 0.75 , and self-efficacy part was 0.76 which was a little lower than Turkish version of HLS (0.84 and 0.83, respectively) (Bahar Özvarış et al., 2018) for Syrian refugees. The reliability-validity results showed that the adopted scale is a valid and reliable tool.

\section{Conclusions}

In conclusion, the detection of health literacy level of Syrians living in Turkey with this reliable scale would contribute to plan various activities such as specific health services and trainings for this group.

\section{Limitations}

The current study has some limitations. The participants of the study were literate 18-60 aged adults. For this reason, it is not appropriate to use this scale for assessing the health literacy level of adolescents and elderly. Since the scale could only be self-administered, it is not suitable for assessing the illiterate people also. Even the participants were recruited from different regions of Turkey, due to the sampling method (convenience sampling), the external validity of the results were week.

\section{Declarations}

\section{Ethics approval and consent to participate}

The ethical approval of Hacettepe University Non-Interventional Clinical Researches Ethics Board was obtained; permission from the Ministry of Internal Affairs Provincial Migration Administration was also taken. The participation was volunteer-based and the data was collected anonymously.

\section{Consent for publication}

Consent was given by all authors.

\section{Availability of data and materials}

The data sets generated and/or analyzed during the current study are not publicly available for now since this study comprises one part of a comprehensive project and other stages are not yet completed, but are available from the corresponding author on reasonable request.

\section{Competing interests}

The authors report no conflict of interest.

\section{Funding}

This study is funded through the UK Research and Innovation GCRF RESEARCH FOR HEALTH IN CONFLICT (R4HC-MENA); developing capability, partnerships and research in the Middle and Near East (MENA) ES/P010962/1. 
Planning and design of the study and interpretation of the results: Şevkat Bahar-Özvarış (ŞBÖ), Bahar Güçiz-Doğan (BGD), Hande Konşuk-Ünlü (HKÜ), Gamze Aktuna (GA), M. Tezer Kutluk (MTK)

Data collection and entry: Tacettin İnandı (Ti), A. Öner Kurt (AÖK), Neriman Aydın (NA)

Data analysis and interpretation: Hande Konşuk-Ünlü (HKÜ)

Writing the manuscript: Şevkat Bahar-Özvarış (ŞBÖ), Bahar Güçiz-Doğan (BGD), Hande Konşuk-Ünlü (HKÜ), Gamze Aktuna (GA)

All authors read and approved the final manuscript.

\section{Acknowledgments}

The authors thank the Syrian refugees voluntarily participated our study for their valuable contributions. The authors also thank the UK Research and Innovation Global Challenges Research Fund (GCRF) grant Research for Health in Conflict (R4HC-MENA) (ES/P010962/1) for supporting this research.

\section{References}

1. Mol: Temporary Protection. https://en.goc.gov.tr/temporary-protection27. Accessed 01 May 2021.

2. MoH: Project Activities. https://www.sihhatproject.org/faaliyetler.html. Accessed 01 May 2021.

3. Castañeda H, Holmes SM, Madrigal DS, Young M-ED, Beyeler N, Quesada J. Immigration as a social determinant of health. Annu Rev Public Health. 2015;36:375-392.

4. Koçan S, Güngördü Demirci N, Demir A, Üstün Ç. Bir Grup Sağlık Çalışanının Bakış Açısıyla Göçmen Sorunu: Nitel Bir Çalışma. Turkish Studies. 2016;12(31):361-378.

5. Alkan A, Erdem E, Çelik R. Sağlık Alanındaki Ayrımcı Tutum ve Davranışlar: Kavramsal Bir İnceleme. Hacettepe Sağlık İdaresi Dergisi. 2016;19(3):365-390.

6. Demir E, Işıl E, Kurt ÖA, Etiler N. Sığınmacıların/Geçici Koruma Altına Alınanların Sağlık Hizmetlerinden Yararlanmasında Mevcut Durum ve Yaşanan Sorunlar, Engeller. Savaş. Göç ve Sağlık. Türk Tabipler Birliği, Ankara. 2016;83-94.

7. Meydanlioglu A, Arikan F, Gozum S. Cultural sensitivity levels of university students receiving education in health disciplines. Advances in Health Sciences Education. 2015;20(5):1195-1204.

8. United Nations: International Migration Report 2017. https://www.un.org/en/development/desa/population/migration/publications/migrationreport/docs/MigrationReport2017_Highlights.pdf. Accessed 01 May 2021.

9. WHO. Health literacy: the solid facts. Copenhagen:WHO Regional Office for Europe; 2013. https://apps.who.int/iris/bitstream/handle/10665/128703/e96854.pdf. Access Date: 05.01.2021. Accessed 01 May 2021.

10. WHO. Track 2: Health literacy and health behaviour. Health promotion. Geneva: World Health Organization; 2020. https://www.who.int/healthpromotion/conferences/7gchp/track2/en. Accessed 01 May 2021.

11. Naus T. Health literacy among migrants in theEU: a collection of best available interventionsand indirect measures. Sci J Public Health. 2018;6(1):1-5.

12. Bahar Özvarış Ş, Güçiz Doğan B, Karadağ Çaman Ö, Konşuk Ünlü H, Doğan N, Gelbal S, Sakarya S. Türkiye'de Okuryazar Erişkin Yaş Grubuna Özgü Sağlık Okuryazarlığı Ölçeği Geliştirilmesi. Hacettepe Üniversitesi. UZERLER Matb. Rek. Turz. San. ve Tic. Ltd. Şti. 2018. ISBN: 978-605-83315-4-9. http://fs.hacettepe.edu.tr/halksagligiens/dosyalar/SOY-kitap_baski\%20.pdf.

13. Kostareva U, Albright CL, Berens E-M, et al. International Perspective on Health Literacy and Health Equity: Factors That Influence the Former Soviet Union Immigrants. International Journal of Environmental Research and Public Health. 2020;17(6):2155.

14. Shaw SJ, Huebner C, Armin J, Orzech K, Vivian J. The role of culture in health literacy and chronic disease screening and management. J Immigr Minor Health. 2009;11(6):460-467.

15. Calvo R. Health Literacy and Quality of Care among Latino Immigrants in the United States. Health Soc Work. 2016;41(1):e44-e51.

16. Mantwill S, Schulz PJ. Does acculturation narrow the health literacy gap between immigrants and non-immigrants-An explorative study. Patient Education and Counseling. 2017;100(4):760-767.

17. Omariba DWR, Ng E. Health literacy and disability: differences between generations of Canadian immigrants. Int J Public Health. 2015;60(3):389-97. 
18. Sørensen K, Van den Broucke S, Fullam J, Doyle G, Pelikan J, Slonska Z. Brand H. Health literacy and public health: A systematic review and integration of definitions and models. BMC Public Health. 2012;12(80):1-13.

19. Poureslami I, Nimmon L, Rootman I, Fitzgerald MJ. Health literacy and chronic disease management: drawing from expert knowledge to set an agenda. Health Promotion International. 2017;32(4):743-754.

20. Berkman ND, Davis TC, McCormack L. Health literacy: What is it? Journal of Health Communication. 2010;15(Sup2): 9-19.

21. Altin SV, Finke I, Kautz-Freimuth S, Stock S. The evolution of health literacy assessment tools: A systematic review. BMC Public Health. 2014;14(1207);1-13.

22. Nutbeam D. Health literacy as a public health goal: a challenge for contemporary health education and communication strategies into the 21st century. Health Promotion International. 2000;15(3):259-267.

23. Nutbeam D. The evolving concept of health literacy. Social Science \& Medicine. 2008;67(12): 2072-2078.

24. Parker RM, Baker DW, Williams MV, Nurss JR. The test of functional health literacy in adults. Journal of general internal medicine. 1995;10(10):537-541.

25. Davis TC, Crouch MA, Long SW, Jackson RH, Bastes P, George RB Bairnsfather LE. Rapid assessment of literacy levels of adult primary care patients. Family Medicine. 1991;23(6): 433-438.

26. Bass PF, Wilson JF, Griffith CH. A shortened instrument for literacy screening. Journal of general internal medicine. 2003;18(12):1036-1038.

27. Weiss BD, Mays MZ, Martz W, Castro KM, DeWalt DA, Pignone MP, Mockbee J, Hale FA. Quick assessment of literacy in primary care: The newest vital sign. Annals of Family Medicine. 2005;3(6):514-522.

28. Al-Jumaili AA, Al-Rekabi MD, Sorofman B. Evaluation of instruments to assess health literacy in Arabic language among Iraqis. Res Social Adm Pharm. 2015;11(6):803-813.

29. Wångdahl J, Lytsy P, Mårtensson L, Westerling R. Health literacy and refugees' experiences of the health examination for asylum seekers a Swedish cross-sectional study. BMC Public Health. 2015;15:1162.

30. WHO: Assessing the health literacy and health communication needs of Syrian refugees in Turkey.

https://www.euro.who.int/_data/assets/pdf_file/0010/465877/Assessing-the-health-literacy-and-health-communication-needs-of-Syrianrefugees-in-Turkey-eng.pdf. Accessed 01 May 2021.

31. Siddiqui R. A comprehensive approach to health literacy: validating the All Aspects of Health Literacy Scale in a representative sample of Arabic-speaking adult Syrian refugees (Unpublished Master thesis). Published online November 2017. Accessed 01 May 2021.

https://macsphere.mcmaster.ca/handle/11375/22159.

\section{Figures}




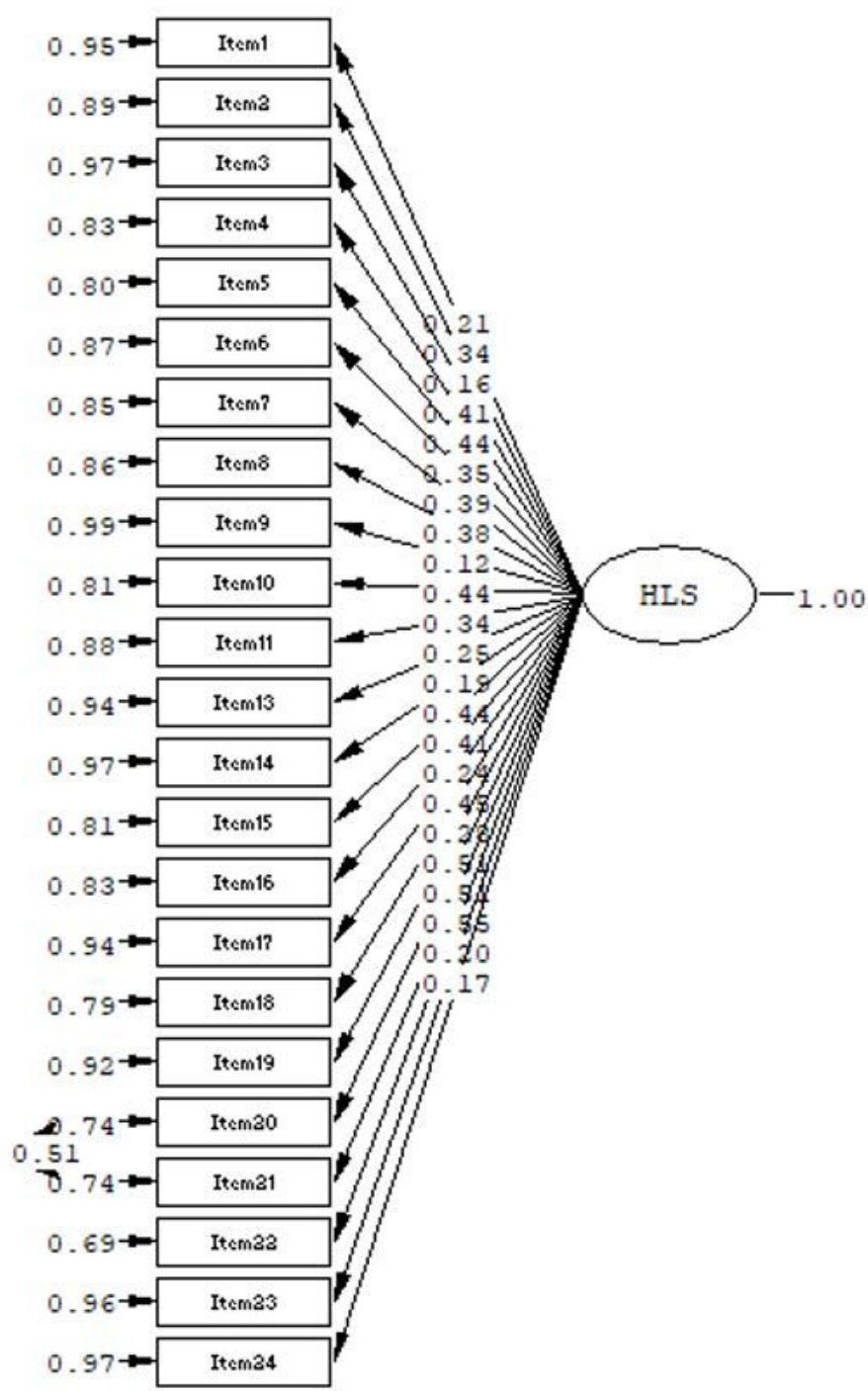

Figure 1

The Path Diagram of Health Literacy part of the Scale 


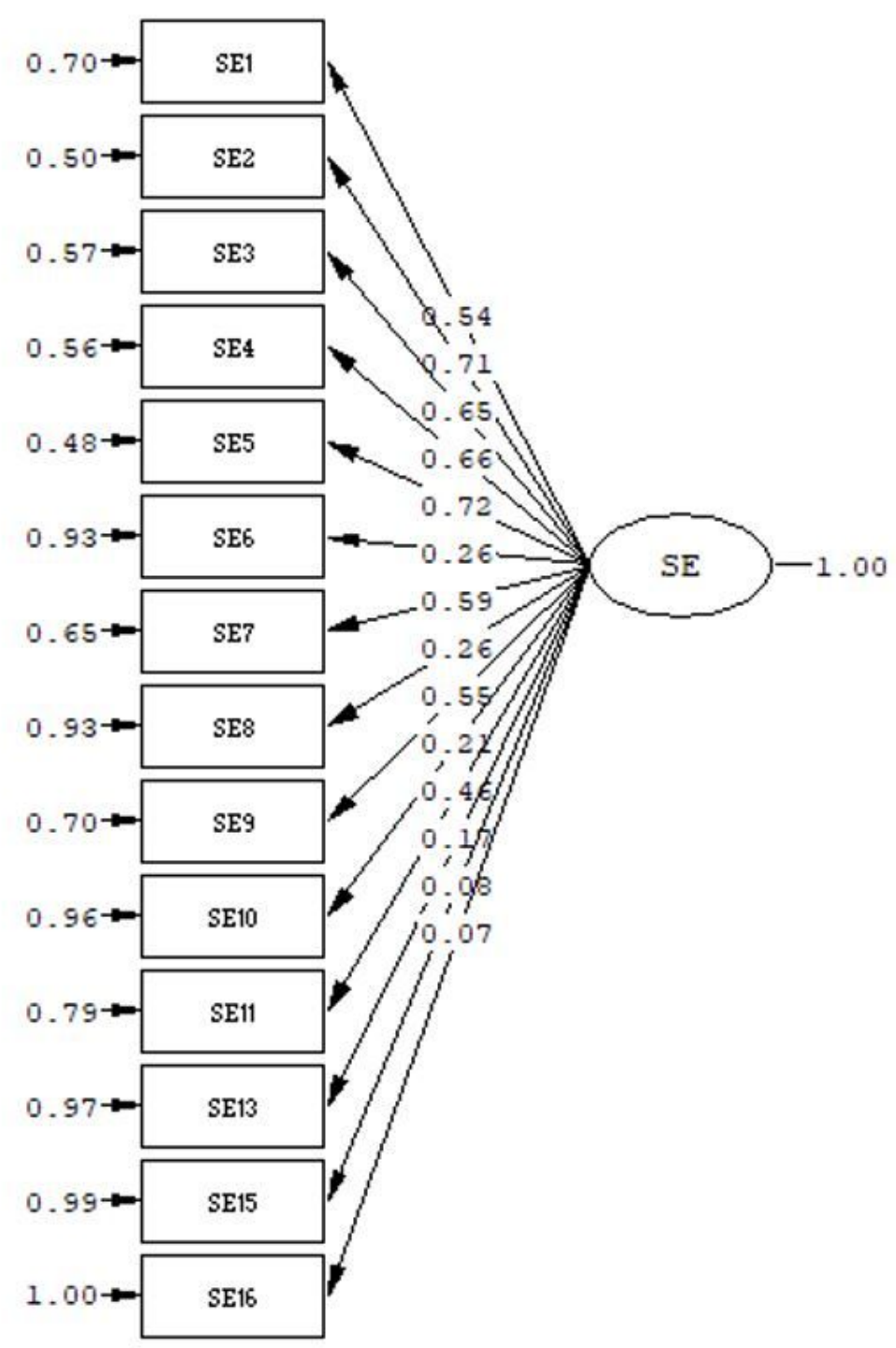

Figure 2

The Path Diagram of Self-Efficacy Part of the Scale 